\title{
PENGARUH KOMBINASI PUPUK ORGANIK TERHADAP PRODUKSI TERUNG (Solanum melongena L) SEBAGAI SUMBER BELAJAR BIOLOGI SMA
}

\author{
Ni Wayan Sutiani \\ Anak Agung Oka \\ Pendidikan Biologi FKIP Universitas Muhammadiyah Metro \\ E-mail: niwayan_sutiani@yahoo.co.id
}

\begin{abstract}
Learning process is most emphasized for how student learn to a concept which can we get from environment. Teacher can exploiting research product as media and source learn to student to be understands concept easier. Data which got to analize pass from Analysis Variation (ANAVA) is obtained from $F_{\text {hit }} 15,98>F_{\text {daf }} 2,35$ in real level 0,05, so that $F_{\text {hit }}>F_{\text {daf }}$, so refuse $H_{0}$ dan $H_{1}$ accepted. While from test "Beda Nyata Jujur" obtained treat B gives best influent for eggplant production, because diferencce between treat $B$ by traet $A, C$, and $D$ is biggest than BNJ value. From this analysis has cocluded there is influence organic fertilizer for eggplant plant, and with combination organic (pen 50\%:compost 50\%) gives best influent for eggplant production. Benefit from research product as resource Biologi program for Senior High School is to supports interest competence based on KTSP and hoped student can apply their comprehension about growth and blooming concept in everyday life, so, in learning activity is most emphasized to skill process.
\end{abstract}

Kata Kunci: kombinasi pupuk organik, produksi terung.

Biologi merupakan salah satu cabang ilmu pengetahuan alam yang memiliki objek kajian menyangkut hidup dan lingkungan. Dalam mempelajari biologi diperlukan syarat tersendiri dengan permasalahan selain penguasaan materi, juga dibutuhkan alat bantu berupa alat peraga dan juga alat eksperimen sebagai sumber belajar yang dapat membantu peserta didik dalam mempelajari konsep-konsep biologi. Penggunaan alat bantu tersebut dapat diwujudkan dalam sebuah percobaan yang melibatkan alam sekitar, sehingga alam sekitar juga dapat digunakan sebagai sumber belajar biologi, karena alam sekitar merupakan sumber belajar yang baik dalam mempelajari biologi.
Pelaksanaan proses pembelajaran biologi di sekolah dalam mencapai tujuan perlu dikembangkan dalam memanfaatkan alam sekitar sebagai objek nyata. Dengan kata lain lingkungan adalah tempat belajar atau laboratorium kedua yang komplek yang dapat menjadi sumber belajar biologi bagi peserta didik. Oleh karena itu dalam pembelajaran biologi metode pengajaran (teori) dan pengamatan secara langsung (eksperimen) dapat membantu peserta didik dalam mencapai tujuan pembelajaran dan membentuk peserta didik yang memiliki daya nalar dan daya pikir yang baik, kreatif, cerdas dalam memecahkan masalah, serta mampu 
mengomunikasikan

gagasannya.

Tanaman terung ialah tumbuhan hijau yang sering ditanam secara tahunan. Secara umum ciri fisik terung tidak jauh berbeda dari karakter terung pada umumnya seperti, bentuk bulat/lonjong, panjang, berkulit mulus, dengan kaliks (tangkai buah) yang besar sesuai ukuran buahnya. Batangnya biasanya berduri, warna bunganya antara putih hingga ungu, dengan mahkota yang memiliki lima lobus dan benang sarinya berwarna kuning. Tanaman terung sangat mudah dibudidayakan dan tidak perlu penanganan yang rumit. Dengan demikian, tanaman terung dapat hidup di dataran rendah dan tinggi.

Berdasarkan hasil pra survei yang telah dilakukan pada tanggal 25 Desember 2011 di Desa Wirata Agung, Seputih Mataram, Lampung Tengah produksi tanaman terung dari tahun ke tahun mengalami penurunan. Menurut hasil pra survei terhadap petani terung di Desa Wirata Agung rata-rata produksi terung yang mereka tanam pada tahun 2010 adalah 8 kwintal $/{ }^{1} / 4$ ha, sedangkan pada tahun 2011 produksinya mengalami penurunan menjadi $6 \mathrm{kwintal} /{ }^{1 / 4}$ ha.

Penurunan produksi terung yang dijumpai pada petani terung di Desa Wirata Agung antara lain disebabkan karena pemupukan berpengaruh terhadap produksi terung. Umumnya para petani terung di Desa Wirata Agung dalam pemupukan terung, belum begitu paham terhadap cara serta dosis pupuk yang diberikan pada setiap penanaman terung. Meskipun petani terung di Desa Wirata Agung telah menggunakan 50 ton/ ${ }^{1 / 4}$ ha kombinasi pupuk organik dan pupuk anorganik, hasil produksi yang didapat pun masih kurang maksimal. Hal ini dapat disebabkan karena petani tidak memperhatikan cara pemberian pupuk pada tanaman terung, biasanya petani terung di Desa Wirata Agung memberi pupuk per tanaman terung dengan asalasalan atau tanpa diukur berapa kebutuhan pupuk per tanaman. Sehingga dari beberapa faktor tersebut, peneliti mencoba menggunakan pupuk alami yaitu pupuk organik (kompos, kandang). Peneliti mencoba mengkombinasikan keduanya yaitu pupuk kompos jerami dengan pupuk kandang kambing, dengan dosis yang berbeda pada tiap perlakuan. Kombinasi dosis yang digunakan dalam penelitian ini adalah pupuk kandang $60 \%$ dan pupuk kompos $40 \%$ pada perlakuan pertama, sedangkan pada perlakuan kedua adalah pupuk kandang $50 \%$ dan pupuk kompos 50\%, dan pada perlakuan ketiga adalah pupuk kandang $40 \%$ dan pupuk kompos 60\%, sedangkan kombinasi pupuk kandang $0 \%$ dan pupuk kompos 0\% sebagai kontrol.

Salah satu bentuk bahan organik yang umum digunakan adalah jerami padi, jerami padi disinyalir memiliki banyak manfaat. Kompos jerami padi ini secara bertahap dapat menambah kandungan bahan organik tanah dan lambat laun akan mengembalikan kesuburan tanah. Oleh sebab itu, pengembalian jerami padi pada lahan pertanian sangat diperlukan untuk mempertahankan kesuburan tanah dan membenahi sifat-sifat tanah yang bermasalah. Jerami padi hasil limbah pertanian sebaiknya tidak dibakar karena jerami dapat dimanfaatkan sebagai pupuk kompos. Umumnya petani di Desa Wirata Agung menurut pengamatan peneliti, banyak yang membakar jerami padi walaupun mereka paham bahwa jerami sangat bermanfaat sebagai pupuk kompos yang sangat penting bagi tanah karena dapat menyuburkan tanaman sehingga mampu meningkatkan produktivitas suatu tanaman.

Selain jerami padi, salah satu bentuk bahan organik umum lainnya yang digunakan adalah kotoran hewan. 
Kotoran hewan dapat dimanfaatkan sebagai bahan baku dalam pembuatan pupuk kandang. Pupuk kandang terbagi menjadi macam pupuk yang didasarkan atas hewan yang menghasilkannya, tiaptiap

kotoran hewan yang kemudian disebut menjadi pupuk kandang tersebut memiliki karakter yang berbeda satu dengan yang lain. Secara umum keunggulan dari pupuk alam yang berbentuk padat adalah dapat memperbaiki sifat fisik, kimia dan sifat biologi tanah. Pupuk kandang dari kotoran kambing memiliki kandungan unsur hara relatif lebih seimbang dibandingkan pupuk alam lainnya karena kotoran kambing bercampur dengan air seninya, hal tersebut biasanya tidak terjadi pada jenis pupuk kandang lain. Bercampurnya air seni yang juga mengandung unsur hara dengan kotoran padat membuat kandungan unsur haranya seimbang.

Dalam meningkatkan produksi juga dituntut untuk tetap menjaga lingkungan agar tidak rusak sehingga tidak menurunkan produktivitas tanah. Sehingga peneliti mencoba untuk mengkombinasikan pupuk organik antara pupuk kompos jerami dengan pupuk kandang kambing, hal ini dilakukan agar unsur hara yang diberikan terhadap tanaman khususnya tanaman terung tersebut dapat seimbang dan saling melengkapi, serta dapat meningkatkan produktivitas tanah yang dapat memperbaiki sifat fisik, kimia dan biologi tanah.

Kombinasi pupuk berarti mencampurkan dua atau lebih jenis pupuk yang menjadi satu untuk suatu tanaman, agar hara yang diperlukan seimbang. Menurut Nasih (dalam Handayani, 2011) menyatakan bahwa "Pupuk adalah suatu bahan yang digunakan untuk mengubah sifat fisik, kimia atau biologi tanah sehingga menjadi lebih baik bagi pertumbuhan tanaman atau suatu bahan yang mengandung satu atau lebih hara tanaman”. Menurut Lingga (1998:32) "Pupuk campuran adalah pupuk yang sengaja dibuat oleh pabrik dengan mencampurkan 2 atau 3 zat (unsur) atau lebih dari satu pupuk”. Dari beberapa pendapat di atas, dapat disimpulkan bahwa kombinasi pupuk adalah mencampurkan dua jenis pupuk atau lebih pada tanaman agar memiliki hara yang seimbang. Pupuk kandang adalah pupuk yang berasal dari kotoran ternak seperti kotoran kambing, kotoran ayam (padat). Menurut Lingga (2005:59) "Pupuk kandang adalah pupuk yang berasal dari kandang ternak, baik kotoran padat dan air kencing yang bercampur".

Adapun kelebihan pupuk kandang menurut William, dkk (1993:33) adalah:

1) Perbaikan struktur tanah

2) Kerapatan masa yang lebih rendah

3) Aerasi yang meningkat dari media perakaran

4) Kapasitas penahan air dalam daerah perakaran

5) Meningkatkan KPK dan pemegangan nutrient lainnya, nitrogen dan fosfor

Pada prinsipnya semua jenis pupuk kandang baik untuk tanaman terung, yang penting adalah pupuk tersebut harus benar-benar matang. Pupuk kandang yang tidak matang akan berbahaya bagi tanaman karena masih mengeluarkan gas selama proses pembusukannya. Ciri-ciri pupuk kandang matang adalah pupuk tidak terasa panas bila tangan dimasukkan ke dalam tengah-tengah gundukan pupuk tersebut. Ciri lainnya, pupuk kandang tidak mengeluarkan bau dan wujud fisiknya sudah menyerupai tanah, tetapi warnanya agak kehitaman. 
Tabel 1. Kandungan Hara yang Terkandung dalam Pupuk Kambing

\begin{tabular}{|c|l|c|}
\hline No & Unsur & $\%$ \\
\hline 1 & Nitrogen & 0,40 \\
2 & Fosfor & 0,30 \\
3 & Kalium & 0,17 \\
4 & Air & 60 \\
\hline
\end{tabular}

Sumber: Yuliarti (2009)

Menurut Lingga (1998:64) "Pupuk kompos berasal dari hasil pelapukan bahan-bahan seperti daun-daunan, jerami, alang-alang, rumput, sampah, dan lain sebagainya. proses pelapukan ini dipercepat dengan bantuan manusia."

Dari pendapat di atas, disimpulkan bahwa pupuk kompos berasal dari bahan-bahan berupa daun-daunan, jerami dan lain-lain, serta dengan bantuan manusia. Adapun kelebihan dalam pupuk kompos antara lain: unsur hara yang terikat dalam senyawa organik yang sukar larut diubah menjadi senyawa organik yang larut sehingga berguna bagi tanaman. Pupuk kompos yang digunakan pada penelitian ini berasal dari jerami.

Jerami padi menurut Arifin (2002:41) menyatakan bahwa:

Jerami padi merupakan suatu limbah utama dibidang pertanian yang mempunyai potensi cukup besar dan belum banyak dimanfaatkan. Di indonesia umumnya jerami padi dibakar setelah panen sebab, jika dibiarkan menumpuk akan menjadi inang penyakit. Untuk mengatasi masalah tersebut perlu adanya usaha pemanfaatan limbah pertanian, salah satu alternatif adalah mengembalikan lagi bahan organik ke dalam tanah.

Hasil penelitian yang dilakukan oleh Balai Penelitian Bioteknologi Perkebunan Indonesia (BPBPI) (dalam
Isro'i:2008) kandungan hara kompos jerami dapat dilihat pada Tabel 2 .

Tabel 2. Komposisi Hara Pupuk Kompos Jerami

\begin{tabular}{|c|l|c|}
\hline No & \multicolumn{1}{c|}{ Kadar } & $\%$ \\
\hline 1 & Rasio C/N & 18,88 \\
\hline 2 & C- organik & 35,11 \\
\hline 3 & Nitrogen $(\mathrm{N})$ & 1,86 \\
\hline 4 & Fosfor $(\mathrm{P})$ & 0,21 \\
\hline 5 & Kalium $(\mathrm{K})$ & 5,35 \\
\hline 6 & Kadar air & 55 \\
\hline 7 & Kalsium $(\mathrm{Ca})$ & 4,2 \\
\hline
\end{tabular}

Sumber: BPBPI (dalam Isro’i: 2008)

Berdasarkan tabel di atas dapat disimpulkan bahwa kompos jerami padi yang telah mengalami penguraian memiliki kandungan hara dengan $\mathrm{C} / \mathrm{N}$ rasio yang telah memenuhi $\mathrm{C} / \mathrm{N}$ rasio kompos yang baik yaitu hanya sekitar 14,88 dan tidak melebihi $\mathrm{C} / \mathrm{N}$ rasio tanah. Dengan demikian kompos jerami padi hasil penguraian dapat diberikan langsung terhadap tanaman.

Berdasarkan latar belakang di atas, dapat dirumuskan masalah dalam penelitian ini yaitu : 1) Apakah ada pengaruh kombinasi pupuk organik terhadap produksi tanaman terung (Solanum melongena L.)?, 2) Pada kombinasi pupuk organik manakah yang memberikan pengaruh terbaik terhadap produksi tanaman terung (Solanum melongena L.)?. Penelitian ini bertujuan untuk 1) Untuk mengetahui pengaruh pupuk organik terhadap produksi tanaman terung (Solanum melongena L.), 2) Untuk mengetahui kombinasi pupuk organik yang memberikan pengaruh terbaik terhadap produksi terung (Solanum melongena L.). Sedangkan manfaat yang diharapkan dari penelitian ini yaitu : 1) Dalam dunia pendidikan sebagai sumber belajar biologi pada bahan kajian pertumbuhan dan perkembangan. 2) Dalam dunia penelitian diharapkan dapat dijadikan 
rajukan bagi peneliti selanjutnya di masa yang akan datang. 3) Masyarakat khususnya petani sebagai informasi tentang kegunaan kombinasi pupuk organik terhadap produksi tanaman terung.

\section{METODE}

Rencana penelitian yang akan dilakukan adalah dengan menggunakan metode eksperimen dan semua tanaman terung yang berada pada bedenganbedengan yang terdiri dari 3 perlakuan ditambah 1 kontrol dan 8 ulangan. Adapun tiap bedengan adalah sebagai berikut:

1. Bedengan A untuk perlakuan 1 kombinasi pupuk organik 60\%:40\% (kandang 60\%:kompos $40 \%)$

2. Bedengan B untuk perlakuan 2 kombinasi pupuk organik 50\%:50\% (kandang 50\%:kompos $50 \%)$

3. Bedengan $\mathrm{C}$ untuk perlakuan 3 kombinasi pupuk organik 40\%:60\% (kandang 40\%:kompos $60 \%)$

4. Bedengan D untuk kombinasi pupuk organik 0\%:0\% (kandang 0\%:kompos $0 \%$ ) sebagai kontrol.

Populasi dalam penelitian ini adalah seluruh tanaman terung yang berada pada bedengan percobaan, yang terdiri dari 4 bedengan dengan 8 ulangan dan 1 kontrol yang tiap bedengannya berukuran 100 x $300 \mathrm{~cm}$, dengan jarak tanam 70 x $70 \mathrm{~cm}$, sehingga tiap bedengannya berisi 10 tanaman terung. Jadi jumlah populasi keseluruhan adalah $10 \times 4=40$ tanaman terung. Sedangkan sampel yang menjadi penelitian ini ada beberapa tanaman yaitu 8 tanaman terung dalam tiap bedengan yang diambil secara acak. Dari tiap bedengan, 8 tanaman terung tersebut sudah merupakan ulangan dari setiap perlakuan. Jadi jumlah kesuluruhan sampel adalah $8 \times 4=32$ tanaman terung. Percobaan yang dapat mewakili dalam hal ini perlu digunakan teknik tertentu yaitu dengan cara Rancangan Acak Kelompok (RAK), karena sampel yang digunakan yaitu dalam satu kelompok. Sebelum pengolahan data, terlebih dahulu dilakukan uji normalitas dan uji homogenitas, kemudian pengolahan data dengan Analisis Varians (ANAVA). Untuk membedakan pengaruh antara perlakuan setelah dilakukan uji ANAVA, akan dianalisis dengan uji lanjut Beda Nyata Jujur (BNJ).

\section{HASIL}

Berdasarkan hasil penelitian yang telah dilakukan diperoleh hasil produksi tanaman terung dapat dilihat padaTabel 3. Untuk rata-rata hasil produksi terung dapat dilihat pada Gambar 1.

Tabel 3. Data Produksi Terung (Solanum melongena L) berdasarkan Perlakuan Kombinasi Pupuk Organik (kandang dengan kompos)

\begin{tabular}{|c|c|c|c|c|c|c|c|c|c|c|}
\hline \multirow{2}{*}{$\begin{array}{l}\text { Perla } \\
\text { kuan }\end{array}$} & \multicolumn{8}{|c|}{ Ulangan } & \multirow[b]{2}{*}{ Jumlah } & \multirow{2}{*}{$\begin{array}{c}\text { Rata- } \\
\text { Rata }\end{array}$} \\
\hline & I & II & III & IV & V & VI & VII & VIII & & \\
\hline A & 1150 & 950 & 1270 & 850 & 1350 & 1000 & 1450 & 970 & 8.990 & 1123,7 \\
\hline B & 1440 & 1500 & 1550 & 1350 & 1600 & 1250 & 1630 & 1450 & 11.770 & 1471,2 \\
\hline C & 950 & 880 & 1000 & 970 & 1200 & 1280 & 1360 & 980 & 8.620 & 1077,5 \\
\hline $\mathrm{D}$ & 900 & 770 & 980 & 850 & 1000 & 860 & 920 & 890 & 7.170 & 896,2 \\
\hline
\end{tabular}




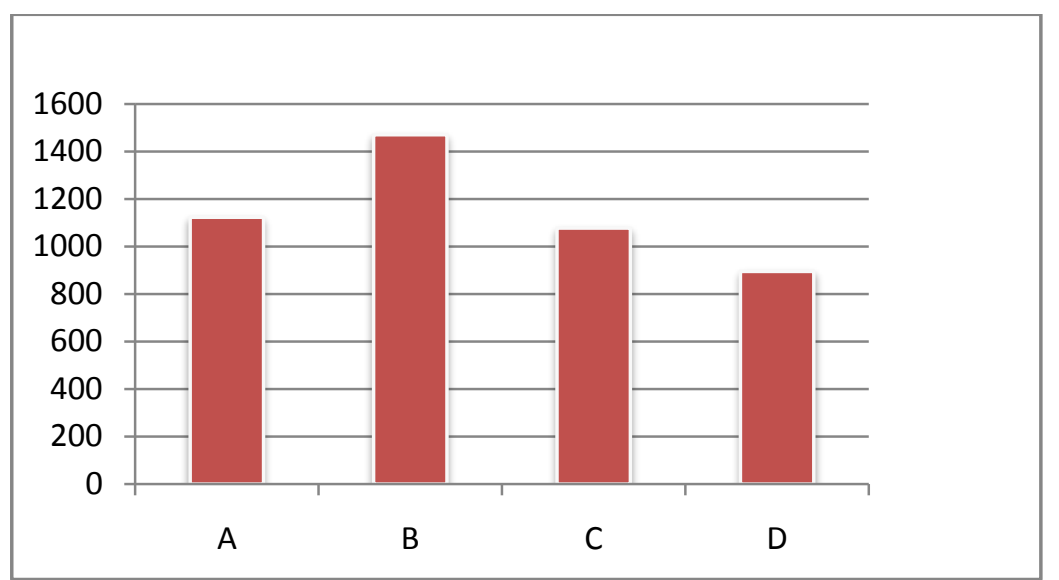

Gambar 1. Diagram Rata-Rata Jumlah Produksi Terung (Solanum melongena L) Keterangan:

A = Perlakuan kombinasi pupuk 60\%:40\%

$\mathrm{B}=$ Perlakuan kombinasi pupuk 50\%:50\%

$\mathrm{C}=$ perlakuan kombinasi pupuk 40\%:60\%

$\mathrm{D}=$ Sebagai kontrol

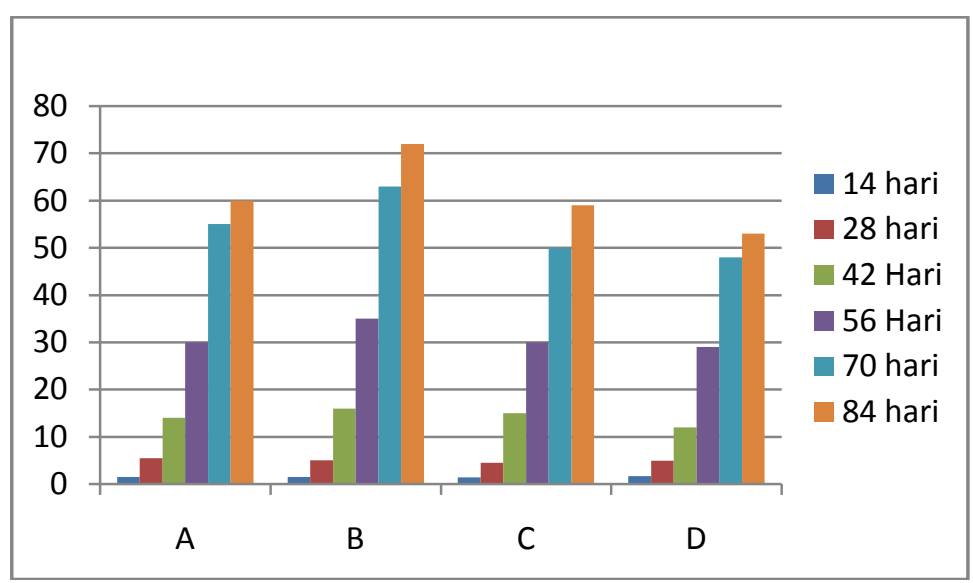

Gambar 2. Diagram Tinggi Batang Tanaman Terung (Solanum melongena L)

Keterangan:

$\mathrm{A}=$ Perlakuan kombinasi pupuk 60\%:40\%

$\mathrm{B}=$ Perlakuan kombinasi pupuk 50\%:50\%

$\mathrm{C}=$ perlakuan kombinasi pupuk 40\%:60\%

$\mathrm{D}=$ Sebagai kontrol

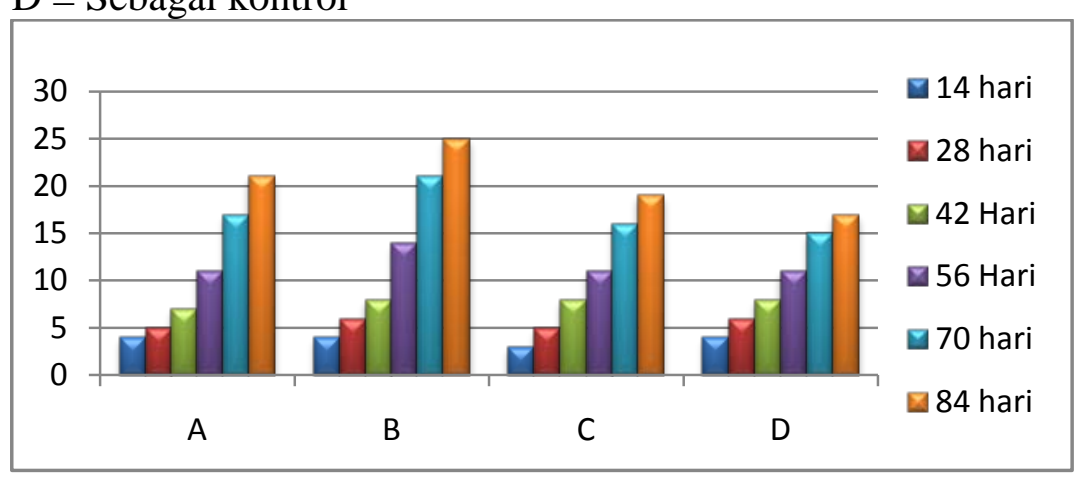

Gambar 3. Diagram Jumlah Daun Tanaman Terung (Solanum melongena L) 
Keterangan:

A = Perlakuan kombinasi pupuk 60\%:40\%

$\mathrm{B}=$ Perlakuan kombinasi pupuk 50\%:50\%

$\mathrm{C}=$ perlakuan kombinasi pupuk 40\%:60\%

$\mathrm{D}=$ Sebagai kontrol

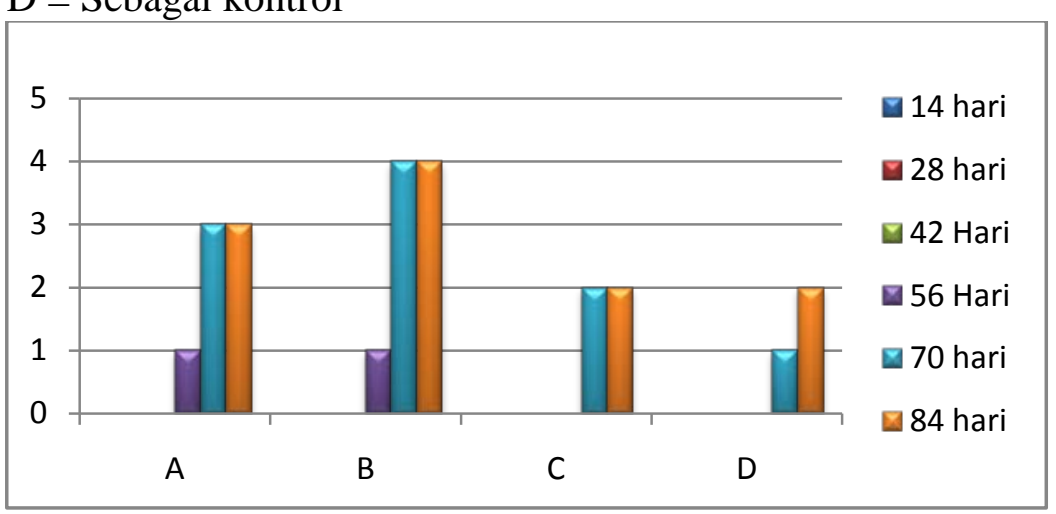

Gambar 4. Diagram Munculnya Bunga Tanaman Terung (Solanum melongena L)

Keterangan:

A = Perlakuan kombinasi pupuk 60\%:40\%

$\mathrm{B}=$ Perlakuan kombinasi pupuk 50\%:50\%

C = perlakuan kombinasi pupuk 40\%:60\%

$\mathrm{D}=$ Sebagai kontrol

Pada penelitian ini selain mengamati produksi terung, peneliti juga mengamati tinggi batang, jumlah daun, dan jumlah munculnya bunga. Data hasil pengamatannya dapat digambarkan pada Gambar 2.

Dari hasil penelitian menunjukkan bahwa produksi tanaman terung dengan 3 perlakuan dan 1 kontrol menunjukkan hasil yang berbeda, serta adanya peningkatan pertumbuhan dan perkembangan pada tanaman terung dari setiap perlakuan. Jika dilihat secara umum, antar perlakuan pada masingmasing diagram di atas menunjukkan adanya pertumbuhan dan perkembangan pada variasi kombinasi pupuk organik (kandang:kompos) yaitu dapat dilihat pada jumlah rata-rata produksinya, pertumbuhan tinggi batang, pertumbuhan jumlah daun, serta perkembangan pada munculnya bunga.

\section{PEMBAHASAN}

Tanaman terung merupakan tumbuhan hijau yang sering ditanam secara tahunan. Secara umum ciri fisik terung tidak jauh berbeda dari karakter buah terong pada umumnya seperti, bentuk bulat/lonjong, panjang, berkulit mulus, dengan kaliks (tangkai buah) yang besar sesuai ukuran buahnya. Selain digunakan sebagai hidangan makanan, Terung dapat dipergunakan sebagai obat tradisional yang banyak bermanfaat untuk kesehatan. Tanah dinyatakan subur bila dapat menyediakan unsur hara dalam jumlah cukup dan seimbang serta mempunyai aerasi yang optimum. Tanah yang terus menerus ditanami tingkat kesuburan tanahnya akan semakin berkurang karena sebagian besar hara yang terdapat di dalamnya akan diangkut keluar oleh tanaman.

Dalam hal ini peneliti menggunakan kombinasi bahan organik 
(kandang:kompos) yang merupakan komponen tanah yang sangat baik untuk memperbaiki struktur dan produktivitas tanah. Penggunaan pupuk organik dapat digunakan untuk mensuplai hara tanaman, memperbaiki sifat fisik, kimia dan biologi pada tanah karena pupuk organik yang berasal dari sisa tanaman dan atau kotoran hewan, yang telah melalui proses fermentasi. Apabila penggunaan pupuk kimia dilakukan dan secara terus menerus justru dapat membahayakan kestrukturan tanah dan berdampak pada kelayakan atau produktivitas tanah di masa yang akan datang.

Berdasarkan hasil data melalui Analisis Variasi (ANAVA) yaitu diperoleh $\mathrm{F}_{\text {hit }}=15,98>\mathrm{F}_{\mathrm{daf}}=2,35$ sehingga tolak $\mathrm{H}_{0}$ dan $\mathrm{H}_{1}$ diterima pada taraf nyata 0,05. Dari data tersebut menunjukkan bahwa kombinasi pupuk organik (kandang:kompos) berpengaruh nyata terhadap produksi terung. Pengaruh perlakuan B (kandang 50\%:kompos 50\%) menunjukkan pengaruh paling baik dibandingkan dengan perlakuan A (kandang 60\%:kompos 40\%), perlakuan C (kandang 40\%:kompos 60\%), dan perlakuan D (kontrol). Hal tersebut dapat terjadi dikarenakan ketersediaan unsur hara yang terkandung pada kombinasi pupuk organik (kandang 50\%:kompos $50 \%)$ telah memenuhi kebutuhan yang dibutuhkan oleh tanaman terung. Pertumbuhan tanaman pada perlakuan B, rata-rata pertumbuhannya normal (subur), hal tersebut dapat dilihat dari pertumbuhan batang yang lebih tinggi serta tumbuh cabang yang banyak, daun yang berwarna hijau dan lebar, munculnya bunga yang lebih banyak, serta buah yang dihasilkan pun lebih besar dan panjang. Unsur hara yang terkandung pada perlakuan B seperti unsur nitrogen diperlukan untuk pertumbuhan vegetatif (merangsang pertumbuhan daun), serta pospor dan kalium diperlukan untuk pertumbuhan generatif (mengangkut energi hasil metabolisme, merangsang pertumbuhan akar, merangsang pembuahan, proses fotosintesis, pengangkutan asimilasi, enzim dan mineral termasuk air). Pada perlakuan A, kombinasi pupuk yang diberikan tidak seimbang begitu juga dengan perlakuan $\mathrm{C}$, sehingga belum dapat mencukupi kebutuhan tanaman untuk pertumbuhan, hal tersebut dapat terlihat dari pertumbuhan batang yang lebih pendek, pertumbuhan daun dan bunga lebih sedikit, serta buah yang dihasilkan pun kecil dan pendek.

Sedangkan pada perlakuan D (sebagai kontrol), pertumbuhan tanaman pada perlakuan ini cukup normal, walaupun pertumbuhannya kurang subur karena tidak mendapatkan unsur hara yang cukup untuk pertumbuhan tanaman terung, tanaman terung dalam perlakuan ini hanya mengandalkan unsur hara yang terdapat dalam media tanah tanpa ada unsur hara lainnya dari luar. Hal tersebut dapat dilihat bahwa pertumbuhan batangnya sangat pendek begitu juga dengan cabang-cabangnya, jumlah daun yang lebih sedikit, serta bunga yang sedikit dan banyak yang gugur, dan hasil produksi yang dihsilkanpun lebih kecilkecil dan sedikit. Kemudian hasil penelitian ini juga dapat dilihat pada perhitungan koefesien keragaman (KK) yang menunjukkan nilai sebesar 632,5\% yang berpengaruh kombinasi pupuk organik terhadap produksi tanaman terung sebesar $632,5 \%$.

Selanjutnya dari hasil BNJ menunjukkan bahwa pada perlakuan B mempunyai hasil BNJ beda nyata dari perlakuan A, C, dan D. Pada perlakuan B (kandang 50\%:kompos 50\%) merupakan perlakuan yang mempunyai berat terung paling besar dan berbeda, dengan demikian kombinasi pupuk organik yang meningkatkan produksi 
terung dalam penelitian ini adalah perlakuan B (kombinasi pupuk kandang 50\%:kompos 50\%) yang mendapat hasil 11.770 gr terung sedangkan apabila tidak diberi pupuk pada perlakuan D (kontrol) hanya mencapai hasil 7.170 gr terung.

Menurut Nasih (dalam Handayani, 2011) menyatakan bahwa "Pupuk adalah suatu bahan yang digunakan untuk mengubah sifat fisik, kimia atau biologi tanah sehingga menjadi lebih baik bagi pertumbuhan tanaman atau suatu bahan yang mengandung satu atau lebih hara tanaman, agar hara yang diperlukan seimbang”.

Dari pendapat di atas dapat diambil pengertian bahwa penggunaan kombinasi pupuk organik (kandang:kompos), dapat memberikan pengaruh pertumbuhan yang lebih baik bagi tanaman. Tanaman juga memerlukan unsur hara dengan takaran yang cukup, sehingga dengan menggunakan kombinasi pupuk organik yang seimbang maka unsur hara yang dapat diserap oleh tanaman akan seimbang dan dapat menghasilkan pertumbuhan dan perkembangan yang lebih baik, serta dapat memperbaiki struktur dan produktivitas tanah. Pada dasarnya semua makhluk hidup memerlukan sumber nutrisi yang sesuai untuk pertumbuhan dan perkembangannya, begitu juga dengan tanaman terung sangat membutuhkan nutrisi yang sesuai untuk pertumbuhannya.

\section{KESIMPULAN DAN SARAN}

\section{Kesimpulan}

Dari hasil penelitian dan pembahasan yang telah penulis lakukan maka dapat diambil kesimpulan sebagai berikut:
1. Kombinasi pupuk organik berpengaruh nyata terhadap berat buah terung.

2. Pemberian kombinasi pupuk organik dengan perbandingan pupuk kandang $50 \%$ dan pupuk kompos 50\% memberikan pengaruh yang paling baik terhadap produksi buah terung.

\section{Saran}

Berdasarkan hasil penelitian maka penulis dapat mengemukakan saran sebagai berikut:

1. Diharapkan kepada petani apabila bercocok tanam terung hendaknya menggunakan sistem pemberian kombinasi pupuk organik yang seimbang yaitu kandang 50\%:kompos $50 \%$.

2. Untuk peneliti selanjutnya agar dapat meneliti media tanam dengan dosis pupuk dan kombinasi pupuk yang berbeda.

3. Bagi guru hasil penelitian ini dapat digunakan sebagai sumber belajar bilogi SMA pada bahan kajian Pertumbuhan dan Perkembangan yang diberikan kepada siswa SMA kelas XII semester 1 .

\section{DAFTAR RUJUKAN}

Arifin. 2002. Sukses Membuat Kompos dari Sampah. Jakarta: Agro Media Pustaka.

Handayani, Eka. 2011. Pengaruh Dosis Pemberian Kompos Jerami Padi dan Pupuk Kandang Sapi Terhadap Produksi Kacang Tanah (Arachis hypogeae L) sebagai Sumber Belajar Biologi SMA Kelas XII pada Materi Pertumbuhan dan Perkembangan TA 2011/2012. Skripsi. Metro: Program Sarjana UM Metro.

Isro’i. 2008. Kompos.Peneliti pada Balai Penelitian Bioteknologi Perkebunan Indonesia, Bogor. www.isroi.org;email:isroi93@gmail .com. 
Lingga, Pinus. 1998. Petunjuk

Penggunaan Pupuk. Jakarta: Penebar

Swadaya.

2005. Petunjuk Penggunaan

Pupuk. Jakarta: Penebar Swadaya.

William, dkk. 1993. Produksi Sayuran di Daerah Tropis. Yogyakarta: Gajah Mada.

Yuliarti. 2009. Penggunaan Pupuk Organik. Yogyakarta: Kasinus. 